\title{
Biotin-avidin mediates the binding of adipose-derived stem cells to a porous $\beta$-tricalcium phosphate scaffold: Mandibular regeneration
}

\author{
ZIHAO FENG，JIAQI LIU，CONGCONG SHEN，NANHANG LU，YONG ZHANG，YANWEN YANG and FAZHI QI
}

Department of Plastic and Reconstructive Surgery, Zhongshan Hospital, Fudan University, Shanghai 200032, P.R. China

Received October 27, 2014; Accepted October 22, 2015

DOI: $10.3892 /$ etm.2015.2961

\begin{abstract}
The present study aimed to investigate the properties of a promising bone scaffold for bone repair, which consisted of a novel composite of adipose-derived stem cells (ADSCs) attached to a porous $\beta$-tricalcium phosphate $(\beta$-TCP) scaffold with platelet-rich plasma (PRP). The $\beta$-TCP powder was synthesized and its composition was determined using X-ray diffraction and Fourier transform infrared spectroscopy. The surface morphology and microstructure of the fabricated porous $\beta$-TCP scaffold samples were analyzed using light and scanning electron microscopy, and their porosity and compressive strength were also evaluated. In addition, the viability of rabbit ADSCs incubated with various concentrations of the $\beta$-TCP extraction fluid was analyzed. The rate of attachment and the morphology of biotinylated ADSCs (Bio-ADSCs) on avidin-coated $\beta$-TCP (Avi- $\beta$-TCP), and untreated ADSCs on $\beta$-TCP, were compared. Furthermore, in vivo bone-forming abilities were determined following the implantation of group 1 (Bio-ADSCs/Avi- $\beta$-TCP) and group 2 (Bio-ADSCs/Avi- $\beta$-TCP/PRP) constructs using computed tomography, and histological osteocalcin (OCN) and alkaline phosphatase (ALP) expression analyses in a rabbit model of mandibulofacial defects. The $\beta$-TCP scaffold exhibited a high porosity $(71.26 \pm 0.28 \%)$, suitable pore size, and good mechanical strength $(7.93 \pm 0.06 \mathrm{MPa})$. Following incubation with $\beta$-TCP for $72 \mathrm{~h}, 100 \%$ of viable ADSCs remained. The avidin-biotin binding system significantly increased the initial attachment rate of Bio-ADSCs to Avi- $\beta$-TCP in the first hour $(\mathrm{P}<0.01)$. Following the addition of PRP, group 2 exhibited a bony-union and mandibular body shape, newly formed bone and increased expression levels of OCN and ALP in the mandibulofacial defect area, as compared with group $1(\mathrm{P}<0.05)$. The results of the present study suggested
\end{abstract}

Correspondence to: Dr Fazhi Qi, Department of Plastic and Reconstructive Surgery, Zhongshan Hospital, Fudan University, 180 Fenglin Road, Shanghai 200032, P.R. China

E-mail: fazhiqifzq@163.com

Key words: $\beta$-tricalcium phosphate, adipose-derived stem cells, platelet-rich plasma, biotin-avidin binding system, bone repair that the novel Bio-ADSCs/Avi- $\beta$-TCP/PRP composite may have potential application in bone repair and bone tissue engineering.

\section{Introduction}

Bone tissue engineering therapy has emerged as a promising strategy for the repair of bone defects $(1,2)$, and consists of three elements: A scaffold, cells and cytokines (3). For an ideal construct, the scaffold should be derived from homologous materials, be biodegradable and provide support for cell retention, and space for cell proliferation and matrix synthesis $(4,5)$. In addition, the seed cells should be autologous, differentiate into osteoblasts, and enhance bone formation and angiogenesis $(6,7)$. The cytokines must be readily produced, exhibit poor immunogenicity, and be able to promote cell proliferation and differentiation into the osteoblast lineage $(8,9)$. Therefore, in order to meet these three requirements simultaneously, it is important to explore novel engineered bone materials.

$\beta$-Tricalcium phosphate $(\beta$-TCP), which is a well-known bioactive ceramic, has been used extensively as a bone substitute due to its similarity to the mineral composition of human bone, excellent biocompatibility and osteoconductivity (10-13). In addition, $\beta$-TCP exhibits a moderate degradation rate to match the rate of osteogenesis $(14,15)$. Furthermore, $\beta$-TCP is able to support the attachment, proliferation and differentiation of various seed cells, including osteoblasts, and adipose- and bone-marrow-derived stem cells $(16,17)$.

Adipose-derived stem cells (ADSCs), which are recognized as a type of mesenchymal stem cell (18), have a similar morphology, differentiation capacity, and phenotype to bone marrow stromal cells (BMSCs) (19). Zuk et al (20,21) initially reported the existence of a mesenchymal stromal/stem cell isolated from adipose tissue, and since then the osteogenic potential of ADSCs in vitro and in vivo has been demonstrated in numerous studies $(19,22,23)$. As compared with BMSCs, ADSCs are easier to obtain and can be harvested in large numbers from small volumes of adipose tissue. In addition, they are associated with a lower donor site morbidity and an increased rate of growth $(24,25)$. ADSCs have a greater potential for application due to their proliferative capacity and ability to maintain their function. Furthermore, the bone-forming capacity of ADSCs has been shown to be greater than that of 
BMSCs $(26,27)$. Therefore, ADSCs are considered an excellent resource for bone tissue engineering.

Platelet-rich plasma (PRP) is an autogenous blood fraction with high platelet concentrations that contains $>300$ active molecules, which influence the tissue regeneration process $(28,29)$. PRP containing various growth factors has been widely used to enhance bone formation $(30,31)$. Furthermore, previous studies have demonstrated that PRP combined with various biomaterials and cell sources exerts positive effects on bone regeneration (32-35). Therefore, PRP is considered to be highly beneficial to bone regeneration.

The present study aimed to investigate the properties of a novel construct for bone regeneration, which was composed of ADSCs attached to a porous $\beta$-TCP scaffold via biotin-avidin bridging and PRP. Its potential application as a scaffold for repairing bone defects was evaluated by analyzing the porosity, compressive strength, in vitro biocompatibility and in vivo bone-forming capacity in a rabbit mandibulofacial defect model.

\section{Materials and methods}

$\beta$-TCP preparation. The $\beta$-TCP powder was synthesized by a modified wet chemical precipitation reaction of $98 \%$ calcium nitrate tetra-hydrate $\left(\mathrm{Ca}\left(\mathrm{NO}_{3}\right)_{2} \bullet 4 \mathrm{H}_{2} \mathrm{O}\right)$ with $99 \%$ diammonium hydrogen phosphate $\left(\left(\mathrm{NH}_{4}\right)_{2} \mathrm{HPO}_{4}\right.$; both Sinopharm Chemical Reagent Co., Ltd., Shanghai, China) (36). Briefly, $\left(\mathrm{NH}_{4}\right)_{2} \mathrm{HPO}_{4}$ solution was prepared at room temperature and mixed with $\mathrm{Ca}\left(\mathrm{NO}_{3}\right)_{2} \bullet 4 \mathrm{H}_{2} \mathrm{O}$ powder, with agitation. The Ca:P ratio was 1:5. The $\mathrm{pH}$ of the mixture solution was maintained at 6.0-8.0 by adding $25 \% \mathrm{NH}_{4} \mathrm{OH}$. The obtained white suspension was stirred for $4 \mathrm{~h}$ and then left to precipitate for $12 \mathrm{~h}$ at $35^{\circ} \mathrm{C}$. The synthesized precipitate was centrifuged at $3,000 \mathrm{x}$ g and washed with distilled water, after which it was dried at $90^{\circ} \mathrm{C}$ for $24 \mathrm{~h}$. Subsequently, the dried powder underwent calcination in an alumina crucible at $700^{\circ} \mathrm{C}$ for $2 \mathrm{~h}$, in order to generate $\beta$-TCP crystals.

The crystalline phase of $\beta$-TCP was investigated using the Ultima IV X-Ray Diffraction (XRD) system (Rigaku, Tokyo, Japan), using monochromated $\mathrm{Cu} K_{\alpha}$ radiation $\left(\lambda=1.5405 \mathrm{~A}^{\circ}\right.$; $20 \mathrm{~mA} ; 40 \mathrm{kV}$ ) in a continuous scan mode. The $2 \theta$ range was $5-80^{\circ}$ at a scanning speed of $8 \% \mathrm{~min}$. XRD data were analyzed using the JADE 6.0 software (Materials Data, Inc., Livermore, CA, USA), and the mean crystallite size $(D)$ was calculated from the XRD line broadening measurement using the Scherrer equation (37): $D=0.89 \lambda / \beta \cos \theta$, where $\lambda$ is the wavelength of the $\mathrm{Cu} K_{\alpha}$ radiation, $\beta$ is the full width at the half maximum of the $\beta$-TCP line, and $\theta$ is the diffraction angle.

$\beta$-TCP crystals were ground in an agate mortar, mixed with dry $\mathrm{KBr}$ powder, and pressed into thin tablets using a manual hydraulic press for $1 \mathrm{~min}$ at $16 \mathrm{MPa}(\mathrm{FW}-4 \mathrm{~A}$; Tianjin Tuopu Instrument Co., Ltd., Tianjin, China). Infrared spectra were obtained using Fourier transform infrared spectroscopy (FTIR; EQUINOX 55; Bruker, Ettlingen, Germany) in the $400-4,000 \mathrm{~cm}^{-1}$ wavenumber range.

Porous scaffold fabrication and characterization. Porous $\beta$-TCP was prepared by mixing $\beta$-TCP powder with ammonium chloride $\left(\mathrm{NH}_{4} \mathrm{Cl}\right)$ pore-forming agent. Briefly, following drying for $24 \mathrm{~h}$ in a dryer, the $\mathrm{NH}_{4} \mathrm{Cl}$ powder was ground in an agate mortar and screened by progressively sieving at 200, 150 , 100 and $60 \mu \mathrm{m}$. Filter materials with an average diameter of $150-200 \mu \mathrm{m}$ and 60-100 $\mu \mathrm{m}$ were selected as the macroporous and microporous pore-forming agents in $\mathrm{NH}_{4} \mathrm{Cl}$, respectively. $\beta$-TCP powder ( $1 \mathrm{~g}), 0.6 \mathrm{~g}$ macroporous pore-forming agent and $0.4 \mathrm{~g}$ microporous agent were transferred into a circular mould and subsequently processed by $1 \mathrm{~min}$ compression moulding (20 Mpa), in order to form a discoid green body (diameter, $10 \mathrm{~mm}$; height, $4 \mathrm{~mm}$ ). Upon sintering the green body using the temperature programming method, a porous $\beta$-TCP scaffold was obtained. In the temperature programming, firstly, the temperature was increased from 20 to $400^{\circ} \mathrm{C}$, for $20 \mathrm{~min}$ at each $20^{\circ} \mathrm{C}$ interval, respectively. Then, the temperature was kept at $400^{\circ} \mathrm{C}$ for $1 \mathrm{~h}$. Subsequently, the temperature was increased from 400 to $1,100^{\circ} \mathrm{C}$, for $30 \mathrm{~min}$ at each $100^{\circ} \mathrm{C}$ interval, respectively. The temperature was kept at $1,100^{\circ} \mathrm{C}$ for $4 \mathrm{~h}$, then decreased to $900^{\circ} \mathrm{C}$. The temperature was kept at $900^{\circ} \mathrm{C}$ for $2 \mathrm{~h}$, then allowed to decrease to room temperature naturally. The surface morphology and microstructure of the porous $\beta$-TCP scaffold were analyzed using a light microscope (CKX41; Olympus Corporation, Tokyo, Japan) and scanning electron microscope (SEM; Nova NanoSEM 600; FEI Company, Hillsboro, OR, USA).

The porosity of the $\beta$-TCP scaffold was measured using Archimedes' Principle, as described in a previous study (38). Briefly, a specific gravity bottle filled with ethanol was weighed $\left(\mathrm{W}_{1}\right)$, and a scaffold sample $\left(\mathrm{W}_{\mathrm{s}}\right)$ was immersed in the bottle in order to allow the infiltration of ethanol into the pores of the scaffold. The air trapped in the scaffold was evacuated under vacuum, after which the bottle was filled with ethanol and the weight of the bottle containing ethanol and scaffold was recorded $\left(\mathrm{W}_{2}\right)$. The ethanol-saturated scaffold was then removed from the bottle, and the weight of the bottle with the residual ethanol recorded $\left(\mathrm{W}_{3}\right)$. The porosity (P) was calculated according to the following equation: $\mathrm{P}=\left(\mathrm{W}_{2}-\mathrm{W}_{3}-\mathrm{W}_{\mathrm{s}}\right) /\left(\mathrm{W}_{1}-\mathrm{W}_{3}\right) \times 100 \%$.

The compressive strength of the $\beta$-TCP scaffold was measured at a loading rate of $0.5 \mathrm{~mm} / \mathrm{min}$ using a universal testing machine (MB028; Quanzhou MeiBang Instrument Co., Ltd, Quanzhou, China), according to the method described in ASTM D695-91 (39). The measurements were performed five times.

Isolation and culture of rabbit ADSCs. Adult New Zealand rabbits ( $\mathrm{n}=3$ per group; age, 4 months; gender, male or female; weight, $\sim 2 \mathrm{~kg}$ ) were provided by the Shanghai Medical College of Fudan University (Shanghai, China), and kept in clean condition (temperature, $16-26^{\circ} \mathrm{C}$; humidity, $40-70 \%$; food and water access, free; one cage per rabbit). These rabbits were anesthetized with an intraperitoneal injection of $10 \%$ chloral hydrate $(3.6 \mathrm{ml} / \mathrm{kg}$; Sigma-Aldrich, St. Louis, MO, USA). Subsequently, the rabbits were placed in the supine position, and the inguinal fat pad was carefully dissected and minced using a sterile razor blade. Following extensive washing with phosphate-buffered saline (PBS; Gibco; Thermo Fisher Scientific, Inc., Waltham, MA, USA), the tissue was enzymatically digested using $0.1 \%(\mathrm{w} / \mathrm{v})$ collagenase type I (Sigma-Aldrich), for $1 \mathrm{~h}$ at $37^{\circ} \mathrm{C}$. The digested tissue was filtered through a 200 mesh sieve, in order to obtain a cell suspension. Following centrifugation at $1,500 \mathrm{x} g$ for $7 \mathrm{~min}$, 
the pellet was resuspended in culture media $(\mathrm{CM})$, consisting of Dulbecco's modified Eagle's media (Gibco; Thermo Fisher Scientific, Inc.), $10 \%$ (v/v) fetal bovine serum (Gibco; Thermo Fisher Scientific, Inc.) and $1 \%(\mathrm{v} / \mathrm{v})$ penicillin/streptomycin solution (Sigma-Aldrich). Cell cultures were maintained at $37^{\circ} \mathrm{C}$ in a humidified atmosphere containing $5 \% \mathrm{CO}_{2}$. Culture media were changed every 1-2 days. Upon reaching $80-90 \%$ cell confluence, the ADSCs were detached using $0.25 \%$ trypsin containing $0.02 \%$ ethylenediaminetetraacetic acid (Invitrogen; Thermo Fisher Scientific, Inc.), and subsequently passaged. All rabbit care and experimental procedures were conducted in accordance with the Animal Care Guidelines of Shanghai Medical College of Fudan University's Animal Ethics Committee.

Surface modifications and in vitro biocompatibility. The cytotoxicity of $\beta$-TCP was investigated by culturing the ADSCs with various concentrations of $\beta$-TCP extracts and then measuring viability using the Cell Counting kit (CCK)-8 quantitative assay (Dojindo Laboratories Co., Inc., Kumamoto, Japan). The extracts were prepared by soaking the scaffold in cell $\mathrm{CM}$ containing $5 \% \mathrm{CO}_{2}$ for $48 \mathrm{~h}$ at $37^{\circ} \mathrm{C}$. Following filtration sterilization, the extracts were diluted with $\mathrm{CM}$ in order to generate serial concentration gradients $(100,50,10$ and $1 \%$; $\mathrm{v} / \mathrm{v})$. ADSCs at passage 4 were detached using $0.25 \%$ trypsin and a $100 \mu \mathrm{l}$ cell suspension was transferred into 96 -well plates at a density of $1 \times 10^{5}$ cells $/ \mathrm{ml}$ per well. Following an attachment period of $24 \mathrm{~h}$ in a humidified atmosphere containing $5 \% \mathrm{CO}_{2}$ at $37^{\circ} \mathrm{C}$, the cells were cultured in the presence of $100 \mu \mathrm{l} \beta$-TCP extracts with various test concentrations. Cells cultured in CM in the absence of $\beta$-TCP served as the control. Following a $72 \mathrm{~h}$ incubation, the cells were washed with D-Hanks buffer solution (Gibco; Thermo Fisher Scientific, Inc.), after which $200 \mu \mathrm{l}$ CCK-8 solution was added to each well. Following a $3 \mathrm{~h}$ incubation at $37^{\circ} \mathrm{C}$, the optical density (OD) at $450 \mathrm{~nm}$ was recorded using a microplate reader (RT-6000; Rayto Life and Analytical Sciences Co., Ltd., Shenzhen, China). Five specimens per group were tested. The cell viability (\% of control) was expressed as the percentage of $\left(\mathrm{OD}_{\text {test }}-\mathrm{OD}_{\text {blank }}\right) /\left(\mathrm{OD}_{\text {control }}-\mathrm{OD}_{\text {blank }}\right)$, where $\mathrm{OD}_{\text {test }}$ is the OD of the cells exposed to $\beta$-TCP extract, $\mathrm{OD}_{\text {control }}$ is the OD of the control sample, and $\mathrm{OD}_{\text {blank }}$ is the OD of the wells without ADSCs.

ADSCs were biotinylated using a commercially available reagent (3-sulfo-NHS-biotin; Pierce Biotechnology, Inc., Rockford, IL, USA). Briefly, $0.5 \mathrm{mg} / \mathrm{ml}$ biotinylation reagent in PBS was prepared prior to the experiments, and the cells $\left(1 \times 10^{6} / \mathrm{ml}\right)$ were treated with $2 \mathrm{ml} \mathrm{3}$-sulfo-NHS-biotin for $30 \mathrm{~min}$ in a $\mathrm{CO}_{2}$ incubator. The biotinylated ADSCs (Bio-ADSCs) were visualized by fluorescence microscopy (DMI4000B; Leica Microsystems GmbH, Wetzlar, Germany) following incubation with avidin-fluorescein isothiocyanate (FITC; Sigma-Aldrich) for $5 \mathrm{~min}$. The extent of biotinylation was determined using flow cytometry (Cytomics FC 500 MPL; Beckman Coulter, Inc., Brea, CA, USA). In order to avidinylate the $\beta$-TCP scaffold (Avi- $\beta$-TCP), the sterilized scaffold was soaked in $2 \mathrm{mg} / \mathrm{ml}$ avidinylation reagent (Pierce Biotechnology, Inc.) at room temperature for $2 \mathrm{~h}$.

Adherence of cells to the $\beta$-TCP scaffold. In order to assess the adherence of the cells to the $\beta$-TCP scaffold, $1 \times 10^{6} / \mathrm{ml}$
ADSCs and Bio-ADSCs were seeded onto the $\beta$-TCP and Avi- $\beta$-TCP scaffolds, respectively. Following 10 and $30 \mathrm{~min}$, and 1,12 and $24 \mathrm{~h}$ of incubation at $37^{\circ} \mathrm{C}, 100 \%$ humidity and $5 \% \mathrm{CO}_{2}$, the cells were collected by trypsinization and were centrifuged at $1,000 \mathrm{xg}$, after which they were washed twice with PBS. Subsequently, $10 \mu \mathrm{l}$ suspension was placed into a hemocytometer in order to measure cell adhesion under a light microscope (Olympus Corporation, Tokyo, Japan). In addition, cellular morphology and attachment were examined by direct visualization under a SEM. Briefly, following a 7 day incubation (media was changed every 2 days), the cell-scaffold constructs were removed, washed twice with PBS and fixed with $2 \%$ glutaraldehyde solution for $30 \mathrm{~min}$ at $4^{\circ} \mathrm{C}$. Subsequently, the constructs were rinsed three times with PBS, followed by $45 \mathrm{~min}$ of fixation with $1 \%$ osmium tetroxide at $4^{\circ} \mathrm{C}$. After rinsing three times with PBS, the fixed constructs were dehydrated and $\mathrm{CO}_{2}$-dried in a desiccator overnight. The samples were sputtered with gold for SEM observation.

Preparation of PRP. Whole blood $(\sim 40 \mathrm{ml})$ was drawn from the heart of a donor rabbit into an anticoagulant, which contained anticoagulant citrate dextrose solution formula A. PRP was obtained via a two-step centrifugation procedure (40). Briefly, whole blood was poured into a $50 \mathrm{ml}$ tube and initially centrifuged at 2,400 x g for $10 \mathrm{~min}$, in order to separate the platelet layer from the plasma and red blood cells. Subsequently, the upper plasma layer and the middle platelet layer were collected and centrifuged again at 3,500 x g for $15 \mathrm{~min}$. The collected precipitated platelets-containing part of the plasma formed the PRP.

Bone regeneration in a rabbit mandibulofacial defect model. Following anesthetization of the rabbits with $10 \%$ chloral hydrate $(3.6 \mathrm{ml} / \mathrm{kg})$, surgical procedures were conducted under sterile conditions. The surgical field of the mandible in each rabbit was shaved and prepared with betadine solution. The mandibular angle and body were exposed via a submental midline skin incision. A full-thickness bone defect $(15 \times 5 \times 4 \mathrm{~mm})$ was created at the mid-portion of the mandible using a reciprocating saw, which was cooled continuously by saline irrigation. The in vivo experiments were divided into two groups ( $\mathrm{n}=3$ rabbits/group): Group 1 (Bio-ADSCs/Avi- $\beta$-TCP), in which the defect was filled with the construct consisting of Bio-ADSCs seeded onto the Avi- $\beta$-TCP scaffold; and group 2 (Bio-ADSCs/Avi- $\beta$-TCP/PRP), in which the defect was filled with the construct consisting of the Bio-ADSCs attached to the Avi- $\beta$-TCP scaffold and PRP. The constructs were prepared by incubating $\sim 1 \times 10^{5}$ Bio-ADSCs with the Avi- $\beta$-TCP scaffold for $24 \mathrm{~h}$ at $37^{\circ} \mathrm{C}$ in a humidified atmosphere containing $5 \% \mathrm{CO}_{2}$. PRP solution $(200 \mu \mathrm{l})$ was added to the constructs prior to implantation. All wounds were routinely sutured and penicillin $(25,000 \mathrm{U} / \mathrm{kg})$ was subcutaneously injected into the rabbits for 3 days post-operation. All rabbits were maintained on a soft diet throughout the study.

Computerized tomography (CT) and histological analyses. Maxillofacial CT images were obtained under general anesthesia and the three-dimensional images were reconstructed using a CT at 4 weeks post-operation (CBCT-NewTom DVT 9000; QR S.r.1., Verona, Italy). 
For histological analysis, all rabbits were sacrificed by air injection into the marginal ear vein, and bone specimens were harvested from each group 4 weeks post-implantation. The constructs Bio-ADSCs/Avi- $\beta$-TCP and Bio-ADSCs/Avi- $\beta$-TCP/PRP that filled the original bone defect area were divided into two parts: Part 1 was used to obtain paraffin-embedded sections for hematoxylin and eosin (H\&E) staining and immunohistochemistry; part 2 was used to generate liquid nitrogen frozen sections for PCR. Part 1 samples were fixed in $10 \%$ neutral buffered formalin and embedded in paraffin. Serial tissue sections $(5 \mu \mathrm{m})$ were obtained for hematoxylin and eosin (H\&E) staining and immunohistochemical analysis. For immunohistochemical analysis, the deparaffinized sections were washed three times in PBS, and endogenous peroxidase was inactivated by incubation with $3 \% \mathrm{H}_{2} \mathrm{O}_{2}$. Nonspecific binding sites were blocked using normal goat serum (Sigma-Aldrich) for $30 \mathrm{~min}$, after which the tissue sections were incubated with mouse anti-osteocalcin (OCN) antibody (1:200; ab13420; Abcam, Cambridge, UK), overnight at $4^{\circ} \mathrm{C}$. After rinsing in PBS three times, the tissue sections were incubated with biotinylated secondary antibody (1:500; Z0420; DAKO, Glostrup, Denmark) at room temperature for $1 \mathrm{~h}$. Peroxidase activity was visualized using $0.05 \%$ diaminobenzidine and $0.03 \% \mathrm{H}_{2} \mathrm{O}_{2}$ in PBS. Subsequently, the tissue sections were counter-stained with hematoxylin for $2 \mathrm{~min}$. At least 10 fields of vision under x200 magnification were captured under brightfield view and images were subsequently analyzed and quantified using ImageJ software, version 1.47 (National Institutes of Health, Bethesda, MA, USA) (41).

Analysis of mRNA expression levels of osteogenic marker genes by reverse transcription-quantitative polymerase chain reaction ( $R T-q P C R)$. Prior to RNA extraction, specimens were homogenized under liquid nitrogen. Total RNA was isolated from each specimen using TRIzol ${ }^{\circledR}$ reagent (Invitrogen; Thermo Fisher Scientific, Inc.) and reverse-transcribed into cDNA using a commercial reverse transcriptase cDNA synthesis kit (Takara Biotechnology Co., Ltd. Dalian, China), according to the manufacturer's protocol. The relative expression levels of the specific osteogenic marker genes OCN and alkaline phosphatase (ALP) were investigated. The primer sequences, which were designed using the Primer Premier 5.0 software (Premier Biosoft International, Palo Alto, CA, USA), were as follows: OCN forward, 5'-GACACCATGAGGACC CTCTC-3', reverse 3'-GGCTCCAGGGGATCTGGG-5'; and ALP forward, 5'-CAGGATTGACCACGGGCACC-3', reverse 3'-GCCTGGTAGTTGTTGTGAGC-5'; GAPDH forward, 5'-TCGTCCTCCTCTGGTGCTCT-3', reverse, 5'-CCACTT TGTGAAGCTCATTTCCT-3'. RT-qPCR was performed under the following cycling conditions using a CFX96 Real-Time System (Bio-Rad Laboratories, Inc., Hercules, CA, USA): $95^{\circ} \mathrm{C}$ for $30 \mathrm{sec}$, followed by 40 cycles at $95^{\circ} \mathrm{C}$ for $5 \mathrm{sec}$, $60^{\circ} \mathrm{C}$ for $20 \mathrm{sec}, 72^{\circ} \mathrm{C}$ for $30 \mathrm{sec}$, and $60-90^{\circ} \mathrm{C}$ for $10 \mathrm{sec} . \mathrm{A}$ 1X TaqMan Universal PCR Master Mix was used throughout (Applied Biosystems; Thermo Fisher Scientific, Inc., Foster City, CA, USA). The glyceraldehyde-3-phosphate dehydrogenase gene served as a normalization control. Relative expression levels were evaluated using the $2^{-\Delta \Delta \mathrm{Cq}}$ method (42). The expression levels of each target gene were analyzed in triplicate.
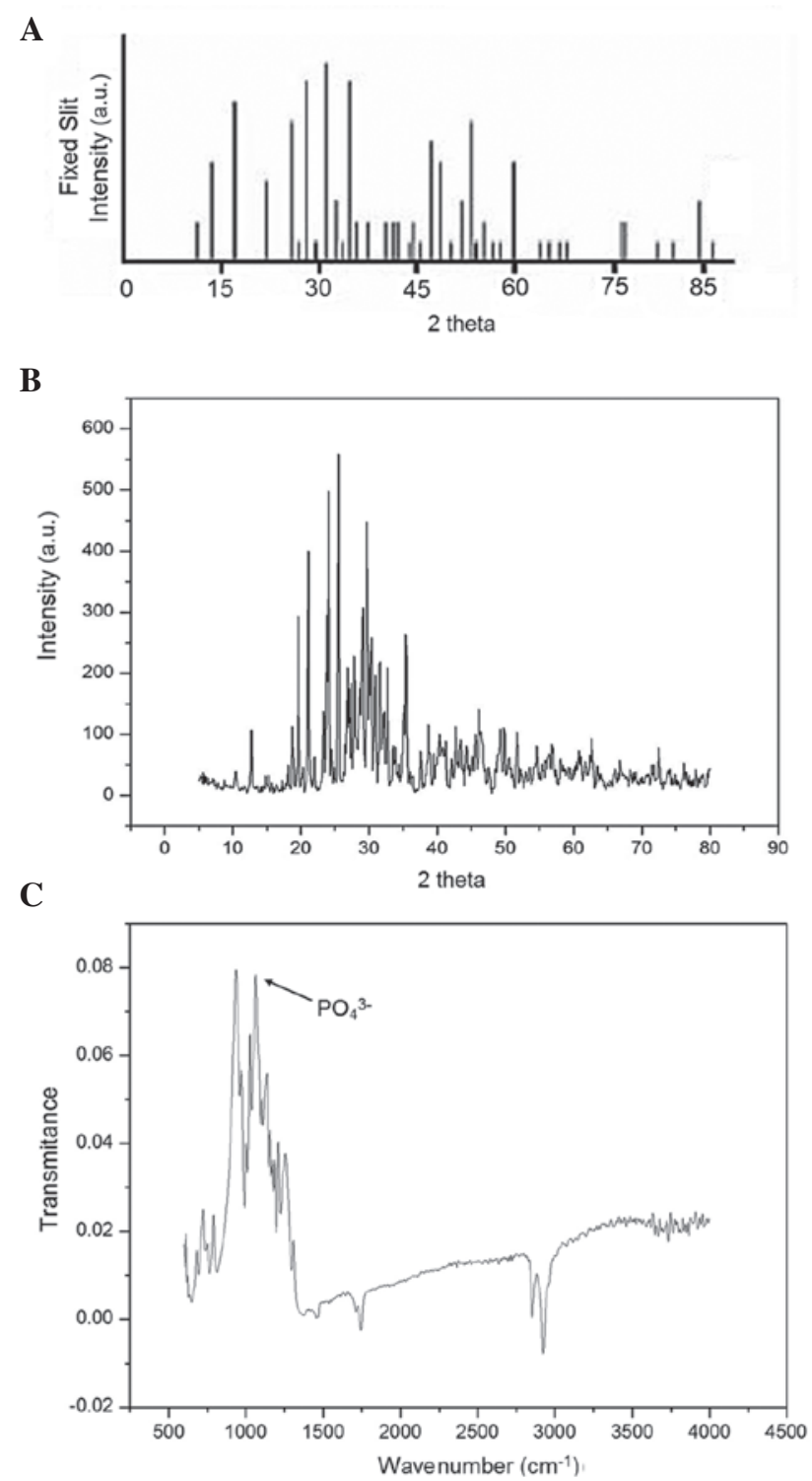

Figure 1. (A) Standard XRD pattern of $\beta$-TCP; (B) XRD pattern and (C) Fourier transform infrared spectroscopy spectrum of the synthesized $\beta$-TCP powder. XRD, X-ray diffraction; $\beta$-TCP, $\beta$-tricalcium phosphate.

Statistical analysis. All statistical analyses were performed using SPSS software, version 19.0 (IBM SPSS, Armonk, NY, USA). Data are presented as the mean \pm standard deviation. One-way analysis of variance was applied for comparisons between groups. Differences between two groups were assessed using Tukey's post-hoc test. $\mathrm{P}<0.05$ was considered to indicate a statistically significant difference.

\section{Results}

Characterization of the $\beta$-TCP scaffold. The XRD pattern and FTIR spectrum of the $\beta$-TCP powder are presented in Fig. 1. The powder exhibited sharp diffraction peaks and had a similar XRD pattern to the standard pattern for $\beta$-TCP (43), indicative of a high crystallinity (Fig. 1A and B). The mean crystallite size of the particles was $31.5 \mathrm{~nm}$. In the FTIR spectrum of the powder, characteristic peaks of $\beta$-TCP were detected at $551,609,944$ and $1,043 \mathrm{~cm}^{-1}$, and the characteristic absorption 

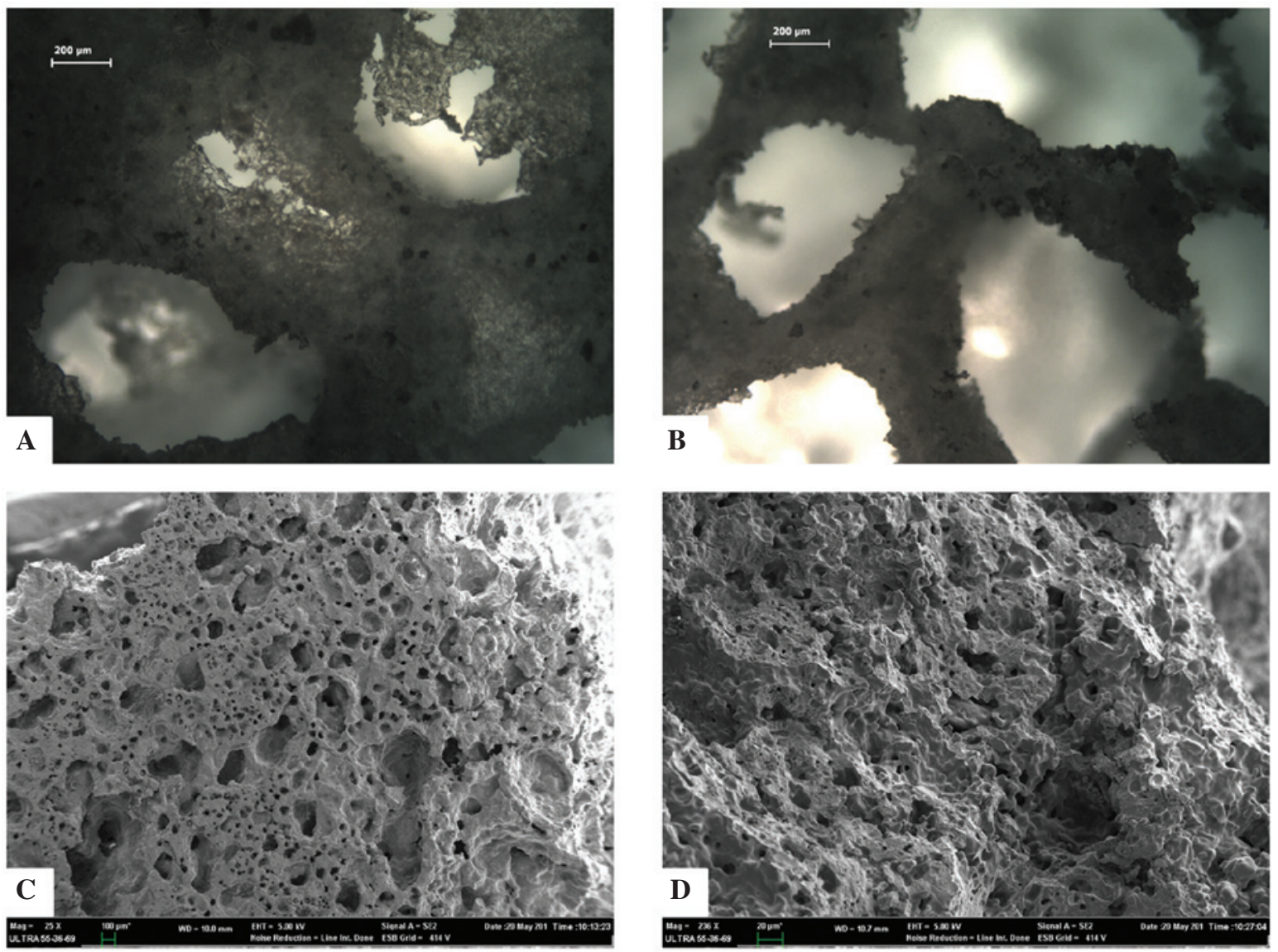

Figure 2. Surface morphology and microstructural characterization of the fabricated porous $\beta$-tricalcium phosphate scaffold samples. Micrographs captured using (A and B) light microscopy (scale bar=200 $\mu \mathrm{m})$ and (C and D) scanning electron microscopy $(C, \mathrm{scale}$ bar $=100 \mu \mathrm{m} ; \mathrm{D}, \mathrm{scale}$ bar=20 $\mu \mathrm{m})$.

Table I. Viability of rabbit adipose-derived stem cells treated with various concentrations of $\beta$-tricalcium phosphate extraction fluid.

\begin{tabular}{ll}
\hline $\begin{array}{l}\text { Extract concentration } \\
(\mathrm{v} / \mathrm{v} ; \%)\end{array}$ & $\begin{array}{l}\text { Cell viability } \\
(\% \text { of control })\end{array}$ \\
\hline 100 & $107.48 \pm 10.32$ \\
50 & $105.63 \pm 9.85$ \\
10 & $108.51 \pm 12.06$ \\
1 & $109.04 \pm 8.17$ \\
\hline
\end{tabular}

bands at 1,200 and $1,000 \mathrm{~cm}^{-1}$ were assigned to components of the $\mathrm{PO}_{4}$ group (Fig. 1C).

The $\beta$-TCP powder could be sintered together effectively, and formed a porous structure containing inter-connected pores, as observed under the CKX41 light microscope (Fig. 2A and B). The SEM micrograph suggested that the porous $\beta$-TCP scaffold had high pore interconnectivity, abundant pore structures, including macropores (diameter, 200-300 $\mu \mathrm{m}$ ) and micropores (size, 60-100 $\mu \mathrm{m}$ ), and a large surface area (Fig. 2C and D). In addition, the porosity and compressive strength of the scaffold were $71.26 \pm 0.28 \%$ and $7.93 \pm 0.06 \mathrm{MPa}$, respectively.

Viability, attachment and morphology of the rabbit ADSCs following incubation with the $\beta$-TCP scaffold. Alterations to

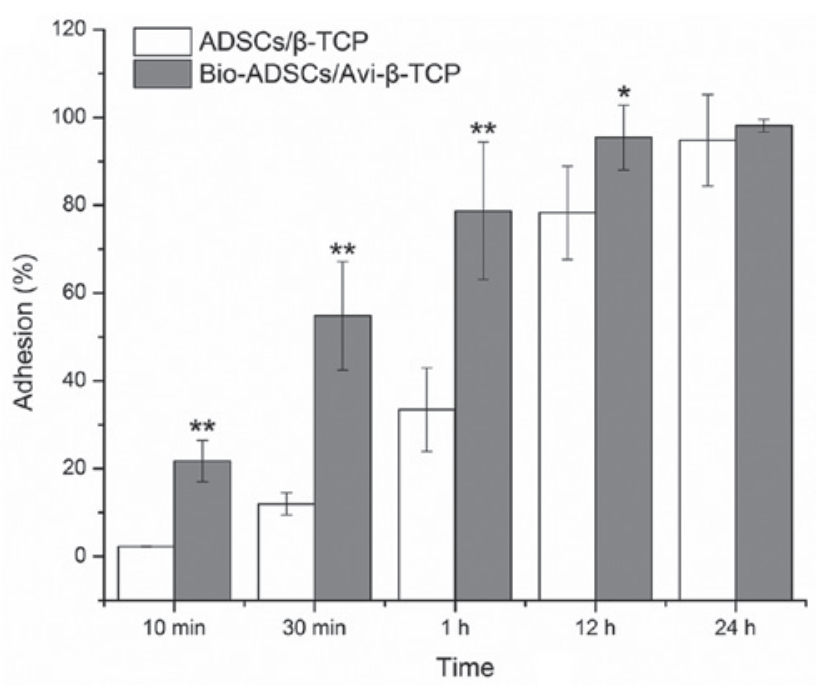

Figure 3. Comparison of the attachment of Bio-ADSCs on Avi- $\beta$-TCP and untreated ADSCs on $\beta$-TCP. Adhesion (\%) following incubation for 10 and $30 \mathrm{~min}$, and 1,12 and $24 \mathrm{~h}$. Data are presented as the mean \pm standard deviation. Significant differences between the ADSCs $\_\beta-T C P$ group and the Bio-ADSCs $\angle$ Avi- $\beta-T C P$ group were detected $\left({ }^{*} \mathrm{P}<0.05 ;{ }^{* * *} \mathrm{P}<0.01\right)$. ADSCs, adipose-derived stem cells; $\beta$-TCP, $\beta$-tricalcium phosphate; Bio-ADSCs, biotinylated ADSCs; Avi- $\beta$-TCP, avidin-coated $\beta$-TCP.

the viability of the ADSCs incubated with various concentrations of the $\beta$-TCP extraction fluid were assessed using the CCK-8 assay (Table I). Following $72 \mathrm{~h}$ of incubation, 100\% 

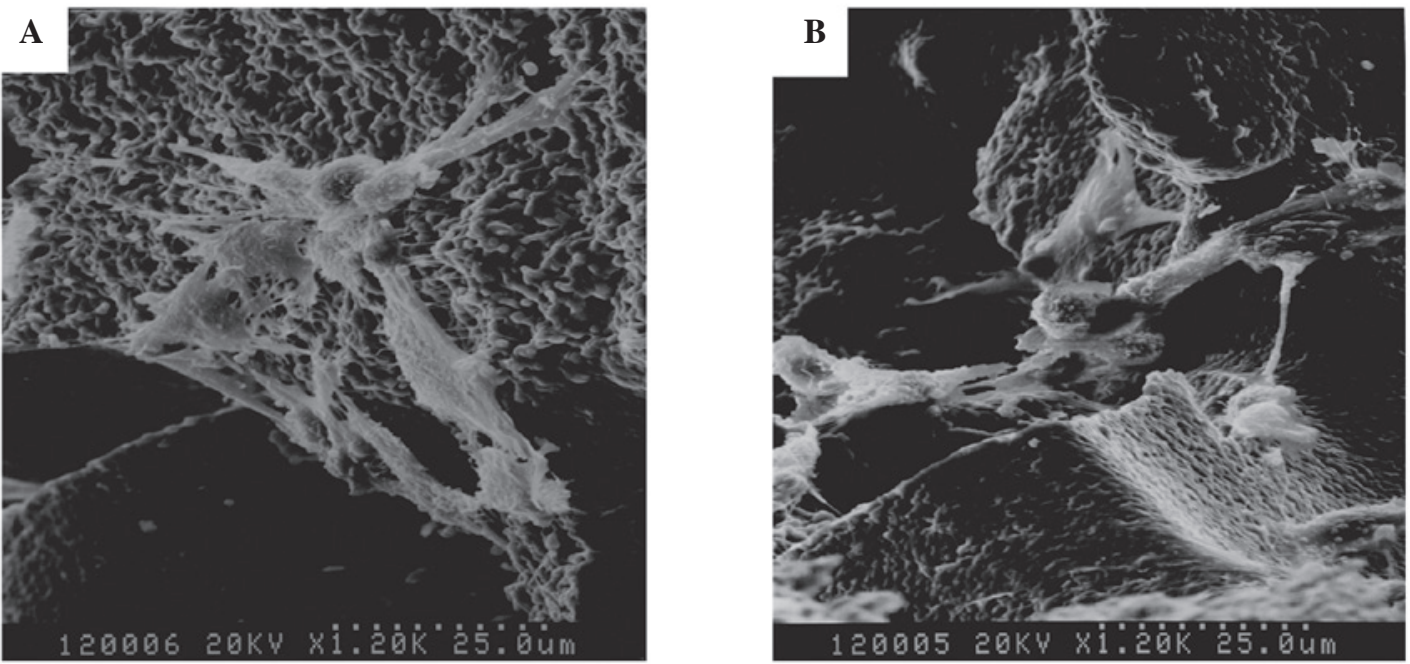

Figure 4. Comparison of the morphology of Bio-ADSCs on Avi- $\beta$-TCP and untreated ADSCs on $\beta$-TCP. Scanning electron microscopy micrographs of (A) ADSCs/ $\beta$-TCP and (B) Bio-ADSCs/Avi- $\beta$-TCP constructs following 7 day incubation (magnification, $\mathrm{x} 1,200$ ). ADSCs, adipose-derived stem cells; $\beta$-TCP, $\beta$-tricalcium phosphate; Bio-ADSCs, biotinylated ADSCs; Avi- $\beta$-TCP, avidin-coated $\beta$-TCP.
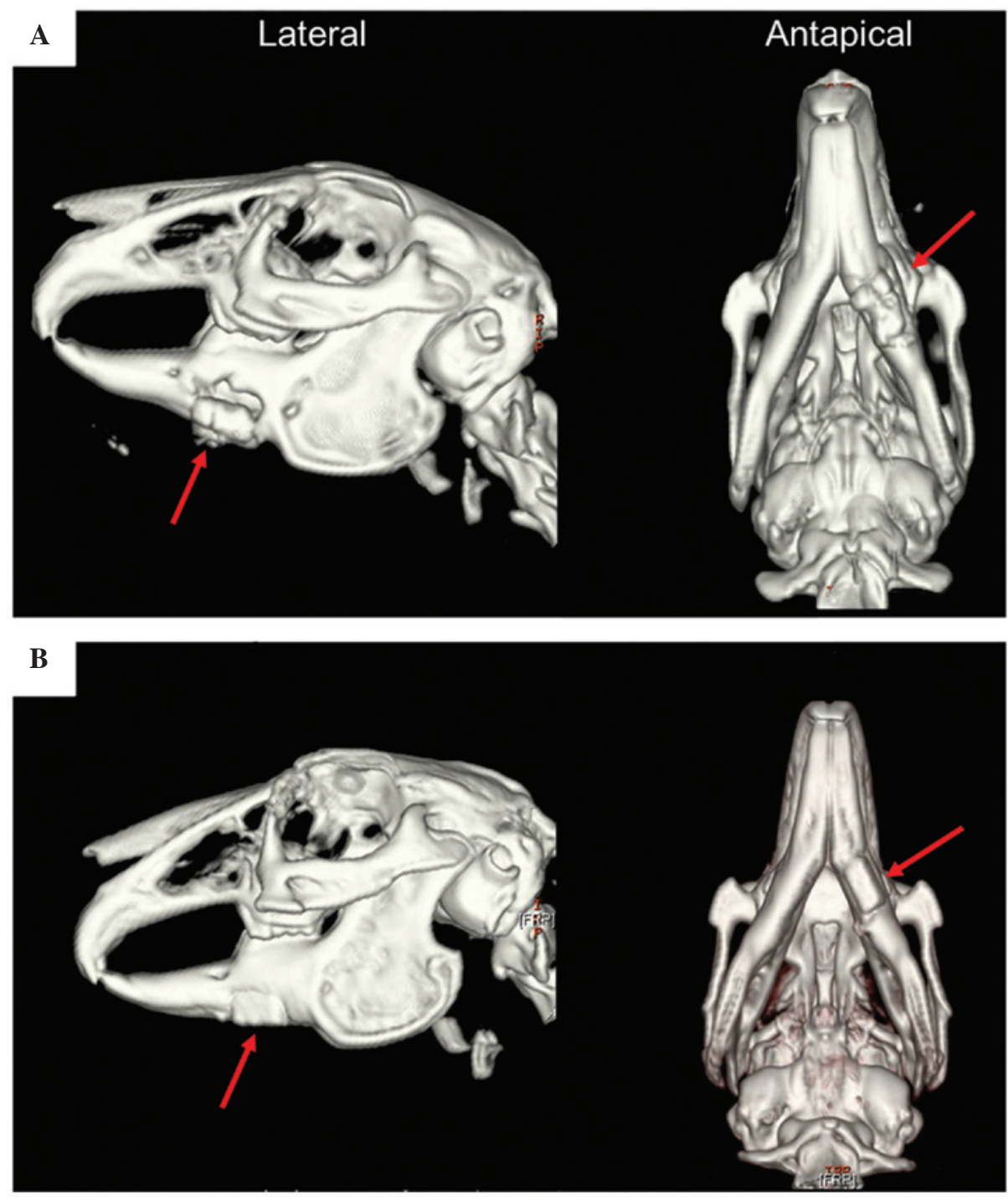

Figure 5. Three-dimensional computed tomography images of mandibular defect reconstruction in the (A) group 1 and (B) group 2 rabbits at 4 weeks post-operation (red arrow). The group 1 and group 2 rabbits received the Bio-ADSCs/Avi- $\beta$-TCP and Bio-ADSCs/Avi- $\beta$-TCP_PRP constructs, respectively. ADSCs, adipose-derived stem cells; $\beta$-TCP, $\beta$-tricalcium phosphate; Bio-ADSCs, biotinylated-ADSCs; Avi- $\beta$-TCP, avidin-coated $\beta$-TCP; PRP, platelet-rich plasma. 

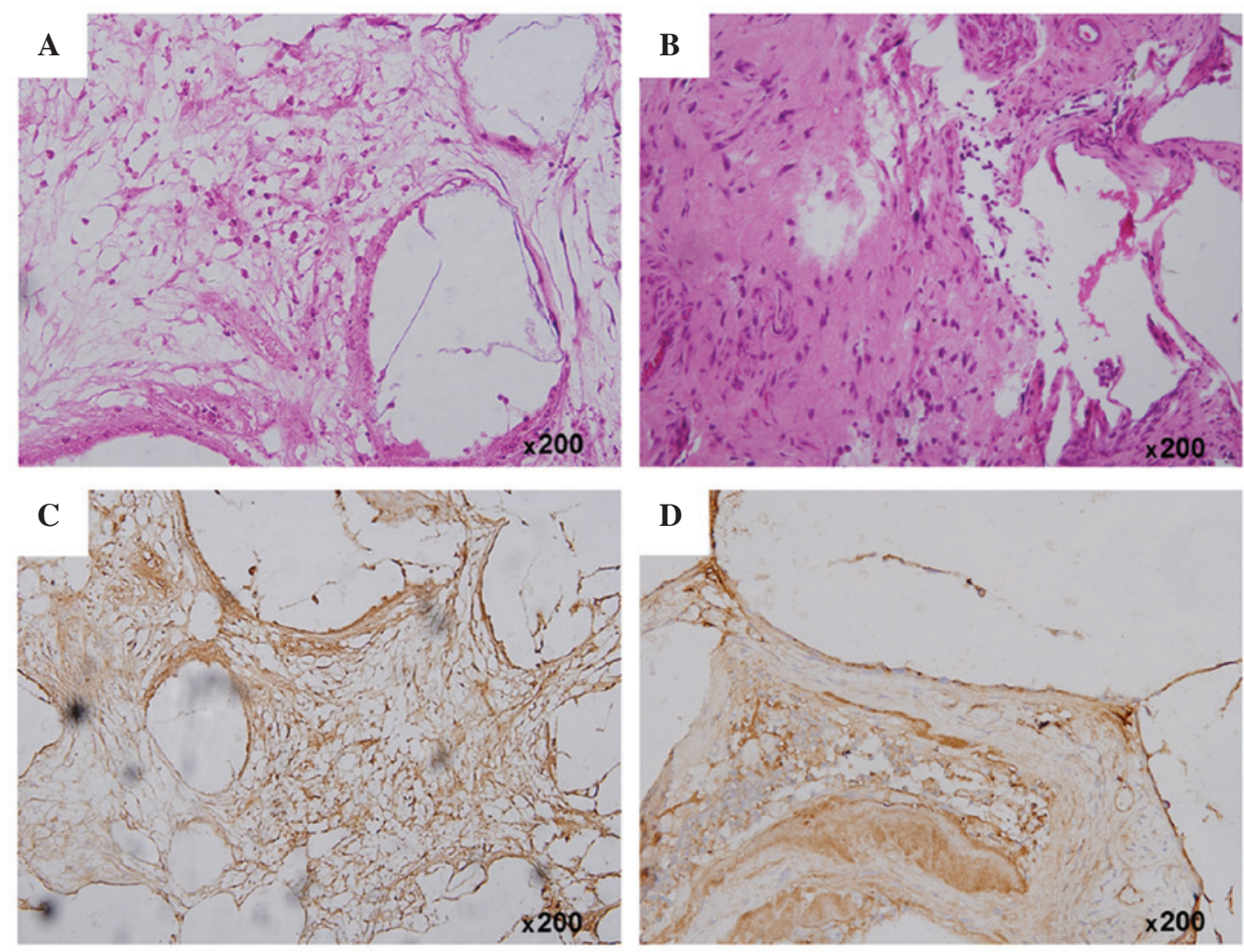

Figure 6. (A and B) Hematoxylin and eosin staining and (C and D) immunohistochemical analysis of osteocalcin protein expression at the mandibular defect area in the (A and C) group 1 and (B and D) group 2 rabbits at 4 weeks post-operation (magnification, x200). The group 1 and group 2 rabbits received the Bio-ADSCs/Avi- $\beta$-TCP and Bio-ADSCs_Avi- $\beta$-TCP/PRP constructs, respectively. ADSCs, adipose-derived stem cells; $\beta$-TCP, $\beta$-tricalcium phosphate; Bio-ADSCs, biotinylated-ADSCs; Avi- $\beta$-TCP, avidin-coated $\beta$-TCP; PRP, platelet-rich plasma.

ADSCs had retained their viability, suggesting that no significant loss in viability was observed, as compared with the control. At the highest extract concentration $(100 \%, \mathrm{v} / \mathrm{v})$ the cell viability was $107.48 \pm 10.32 \%$ of the control. These results suggest that the $\beta$-TCP scaffold does not exert toxic effects on ADSCs.

Bio-ADSCs attach to Avi- $\beta$-TCP. Following biotinylation, ADSCs were incubated with avidin-FITC. All Bio-ADSCs were green in appearance under a fluorescence microscope, whereas the untreated control cells did not exhibit fluorescence (images not shown), thus suggesting that the biotinylation procedure was successful. The degree of biotinylation was calculated to be $95 \%$ of cells using fluorescence correlation microscopy. Subsequently, the Bio-ADSCs and ADSCs were incubated with the Avi- $\beta$-TCP and $\beta$-TCP scaffolds, respectively, in order to evaluate cell adhesion (Fig. 3). In the first hour of incubation, the biotin-avidin interaction significantly enhanced the rate of cell attachment, as compared with the ADSCs/ $\beta$-TCP mixture $(\mathrm{P}<0.01)$. After $12 \mathrm{~h}, 95.46 \pm 7.38 \%$ of Bio-ADSCs were attached to the Avi- $\beta$-TCP scaffold, which was significantly increased, as compared with the ADSCs $/ \beta$-TCP group $(78.29 \pm 10.63 \% ; \mathrm{P}<0.05)$. However, there was no significant difference in adhesion between the two groups after $24 \mathrm{~h}$ of incubation ( $\mathrm{P}>0.05$; Fig. 3).

Morphology of ADSCs/ $\beta-T C P$ and Bio-ADSCs/Avi- $\beta-T C P$ constructs under SEM exhibits no visible difference. All cells were attached and exhibited a morphologically normal appear-

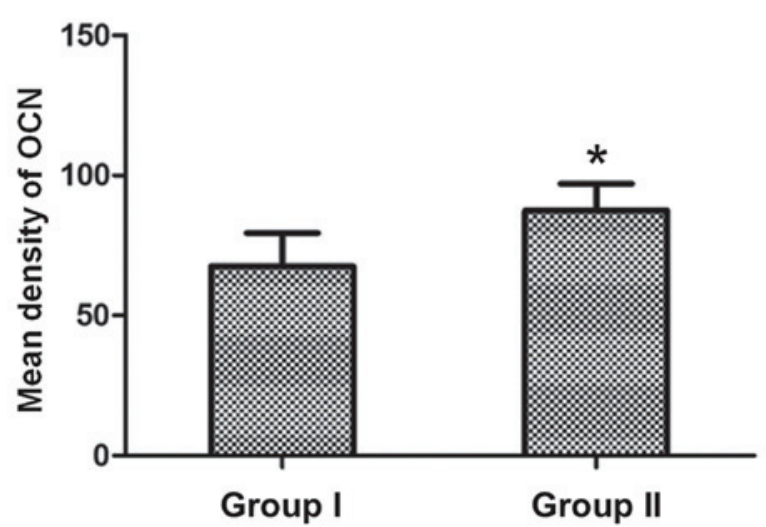

Figure 7. Quantification of the mean density of OCN protein expression levels using Image J software. Data are presented as the mean \pm standard deviation. ${ }^{*} \mathrm{P}<0.05$, vs. group 1 rabbits. OCN, osteocalcin.

ance on the surface of the scaffolds following incubation for 1 day. A large number of ADSCs were firmly attached to the surface and around the pores, and a few cells were enclosed within the three-dimensional scaffolds following 4 days of incubation. At 7 days, pseudopodia extending from the cells were connected with each other and covered the pores. In addition, the cells were embedded in the interspaces of the scaffolds and the secretion of extracellular matrix (ECM) (Fig. 4A and B).

$C T$ analysis. In order to analyze the three-dimensional structure of the repaired mandibles, 3D-CT images were captured 
A

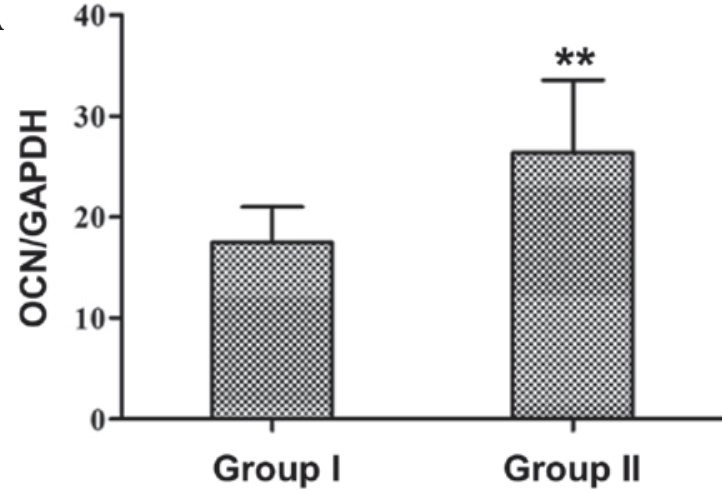

B

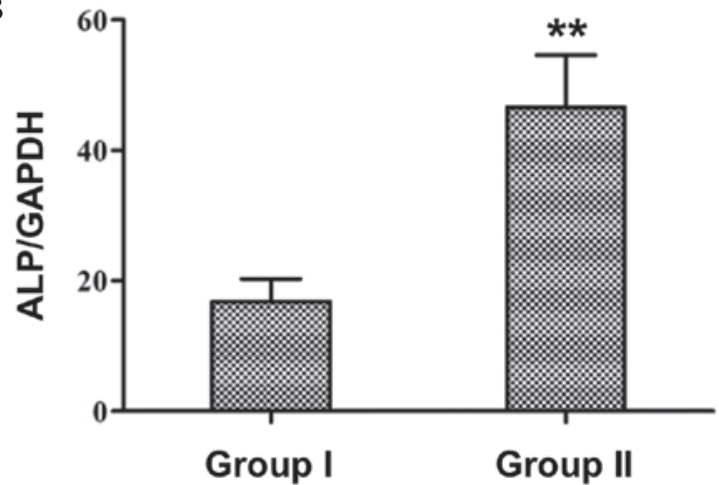

Figure 8. Relative mRNA expression levels of (A) OCN and (B) ALP in the group 1 and group 2 rabbits were quantified using reverse transcription-quantitative polymerase chain reaction. Expression levels were normalized to the housekeeping gene GAPDH. Group 1 and group 2 rabbits received the Bio-ADSCs/Avi- $\beta$-TCP and Bio-ADSCs/Avi- $\beta$-TCP/PRP constructs, respectively. Data are presented as the mean \pm standard deviation. ${ }^{* *} \mathrm{P}<0.01$, vs. group 1 rabbits. OCN, osteocalcin; ALP, alkaline phosphatase; ADSCs, adipose-derived stem cells; $\beta$-TCP, $\beta$-tricalcium phosphate; Bio-ADSCs, biotinylated-ADSCs; Avi- $\beta$-TCP, avidin-coated $\beta$-TCP; PRP, platelet-rich plasma; GAPDH, glyceraldehyde-3-phosphate dehydrogenase.

4 weeks post-operation. In group 1 rabbits, which received the Bio-ADSCs/Avi- $\beta$-TCP construct, only a poor bony union was achieved and the graft appeared to slide out of its groove (Fig. 5A). Conversely, in the group 2 rabbits, which received the Bio-ADSCs/Avi- $\beta$-TCP/PRP construct, a good bony union was achieved and the mandible shape resembled that of normal edentulous mandibles (Fig. 5B).

Histological analysis. Following implantation for 4 weeks, $\mathrm{H} \& \mathrm{E}$ staining detected neogenetic bone-like structure within the area of the Bio-ADSCs/Avi- $\beta$-TCP implant in group 1 rabbits (Fig. 6A). Conversely, in group 2 rabbits, the amount of newly formed bone was markedly increased and was shown to have integrated to form matured interwoven bone and trabecular bone (Fig. 6B).

Immunohistochemical analysis of $\mathrm{OCN}$ protein expression detected new bone formation within the positively-stained area (brown color), and OCN protein expression was markedly upregulated in the defect area at 4 weeks (Fig. 6C and D). In addition, the quantitative analysis suggested that the OCN protein expression was increased in the group 2 rabbits, as compared with the group 1 rabbits $(87.41 \pm 9.65$ vs. $67.53 \pm 11.87$; $\mathrm{P}<0.05$; Fig. 7).

Analysis of gene expression. The mRNA expression levels of the osteospecific genes OCN and ALP in the tissues surrounding the two graft constructs were analyzed at 4 weeks post-implantation. RT-qPCR demonstrated that the relative expression levels of OCN and ALP were significantly increased in group 2 rabbits, as compared with group 1 rabbits $(\mathrm{OCN}$ : 26.38 \pm 7.17 vs. $17.49 \pm 3.52$; ALP: $49.62 \pm 8.34$ vs. $15.12 \pm 4.21$; $\mathrm{P}<0.01$; Fig. $8 \mathrm{~A}$ and $\mathrm{B})$.

\section{Discussion}

Bone tissue engineering has been widely studied and typically involves combining scaffolds with various growth factors and cell sources (22). Searching for an optimal scaffold for bone regeneration remains an unsolved and interesting challenge for researchers. In the present study, the porous $\beta$-TCP scaffold exhibited a high porosity, suitable pore size and good mechanical strength. The high-affinity avidin-biotin binding system increased the initial attachment of ADSCs to $\beta$-TCP. In addition, the use of PRP significantly improved the quality of bone healing in a rabbit mandibulofacial defect model. These results suggested that the Bio-ADSCs/Avi- $\beta$-TCP/PRP composite may have potential application in bone tissue engineering.

Various material properties, including composition, geometry, porosity, size, and microstructure, are important parameters to consider when evaluating appropriate bone formation (44). Previous studies have demonstrated that a high porosity is critical for bone regeneration, as it allows sufficient void space for the ingrowth of surrounding bone and vascularized tissue $(27,45,46)$. Furthermore, the osteogenic capability of composites has been shown to increase with increasing scaffold porosity (45). In addition, small pores may induce osteochondral formation prior to osteogenesis due to relative hypoxic conditions, whereas large pores may lead to direct osteogenesis by simultaneous vascularization due to a high oxygen content (47). Therefore, the pore size of the scaffold is an important parameter for bone tissue engineering. A previous study reported that the minimal pore size for bone regeneration was $\sim 100 \mu \mathrm{m}$ (48). In the present study, the $\beta$-TCP scaffold had a high porosity $(71.26 \%)$ and was able to provide a suitable pore size, including 200-300 $\mu \mathrm{m}$ macropores and 60-100 $\mu \mathrm{m}$ micropores, for bone regeneration, in accordance with the results from previous studies $(17,49)$.

The ability of seed cells to adhere to the biomaterial is a prerequisite and crucial step in various tissue engineering applications $(50,51)$. Numerous strategies have been applied in order to improve affinities between cells and biomaterial surfaces, including ECM adhesion proteins (52), conjugating peptides containing cell-binding sequences (53), and antibodies targeting cell-membrane antigens (54). In addition, previous studies have suggested that the utilization of an avidin-biotin binding system may enhance cell adhesion to biomaterial surfaces $(51,55)$. In the present study, biotinylated ADSCs adhered to the avidin-coated $\beta$-TCP scaffold at a faster rate, as compared with untreated cells. Furthermore, the binding system markedly enhanced the initial 
cell adhesion in the first hour, as previously reported $(51,56)$. These results suggested that the avidin-biotin system may be applied to bone tissue engineering.

Previous studies have demonstrated that PRP, which is a platelet concentrate of autogenous blood, has an important role in tissue repair mechanisms and may exert potential positive effects in the course of bone formation (57-60). In addition, PRP may improve osteochondral healing (61) and increase new bone formation (57). Furthermore, PRP has demonstrated success when applied to orthopedic and dental bone reconstruction surgeries (62). The present study demonstrated that the Bio-ADSCs/Avi- $\beta$-TCP graft loaded with PRP exhibited enhanced bone regeneration and healing properties, as compared with the scaffold untreated by PRP, based on radiological, histological and gene expression analyses. These results suggested that the addition of PRP may significantly enhance new bone formation and improve the quality of bone healing.

In conclusion, the fabricated porous $\beta$-TCP scaffold had a high porosity and suitable pore size, and the utilization of an avidin-biotin binding system increased the adherence of Bio-ADSCs to the Avi- $\beta$-TCP scaffold. Furthermore, the addition of PRP increased the rate of new bone formation and improved the quality of bone healing. These results suggested that the novel Bio-ADSCs/Avi- $\beta$-TCP/PRP composite has potential application in bone repair and bone tissue engineering.

\section{References}

1. Damaraju S and Duncan NA: Stem cell-based tissue engineering for bone repair. In: Tissue Engineering. Fernandes PR and Bartolo PJ (eds). Vol 31. Springer, Dordrecht, The Netherlands, pp1-30, 2014.

2. Liu Y, Zhou Y, Feng H, Ma GE and Ni Y: Injectable tissue-engineered bone composed of human adipose-derived stromal cells and platelet-rich plasma. Biomaterials 29: 3338-3345, 2008.

3. Buser Z,Liu J, Thorne KJ, Coughlin D and Lotz JC: Inflammatory response of intervertebral disc cells is reduced by fibrin sealant scaffold in vitro. J Tissue Eng Regen Med 8: 77-84, 2014.

4. Ravichandran R, Venugopal JR, Sundarrajan S, Mukherjee S and Ramakrishna S: Precipitation of nanohydroxyapatite on PLLA/PBLG/Collagen nanofibrous structures for the differentiation of adipose derived stem cells to osteogenic lineage. Biomaterials 33: 846-855, 2012.

5. Chang NJ, Lam CF, Lin CC, Chen WL, Li CF, Lin YT and Yeh ML: Transplantation of autologous endothelial progenitor cells in porous PLGA scaffolds create a microenvironment for the regeneration of hyaline cartilage in rabbits. Osteoarthritis Cartilage 21: 1613-1622, 2013.

6. Szpalski C, Barbaro M, Sagebin F and Warren SM: Bone tissue engineering: Current strategies and techniques - part II: Cell types. Tissue Eng Part B Rev 18: 258-269, 2012.

7. Khaled EG, Saleh M, Hindocha S, Griffin M and Khan WS: Tissue engineering for bone production-stem cells, gene therapy and scaffolds. Open Orthop J 5 (Suppl 2): S289-S295, 2011.

8. Cha C, Liechty WB, Khademhosseini A and Peppas NA: Designing biomaterials to direct stem cell fate. ACS Nano 6: 9353-9358, 2012.

9. Mosna F, Sensebé L and Krampera M: Human bone marrow and adipose tissue mesenchymal stem cells: A user's guide. Stem Cells Dev 19: 1449-1470, 2010.

10. Farzadi A, Solati-Hashjin M, Bakhshi F and Aminian A: Synthesis and characterization of hydroxyapatite/ $\beta$-tricalcium phosphate nanocomposites using microwave irradiation. Ceram Int 37: 65-71, 2011.

11. Kolk A, Handschel J, Drescher W, Rothamel D, Kloss F, Blessmann M, Heiland M, Wolff KD and Smeets R: Current trends and future perspectives of bone substitute materials - from space holders to innovative biomaterials. J Craniomaxillofac Surg 40: 706-718, 2012.
12. Miyaji H, Yokoyama H, Kosen Y, Nishimura H, Nakane $K$, Tanaka S, Otani K, Inoue K, Ibara A, Kanayama I, et al: Bone augmentation in rat by highly porous $\beta$-TCP scaffolds with different open-cell sizes in combination with fibroblast growth factor-2. J Oral Tissue Engin 10: 172-181, 2013.

13. Zheng H, Bai Y, Shih MS, Hoffmann C, Peters F, Waldner C and Hübner WD: Effect of a $\beta$-TCP collagen composite bone substitute on healing of drilled bone voids in the distal femoral condyle of rabbits. J Biomed Mater Res B Appl Biomater 102: 376-383, 2014.

14. Rezwan K, Chen QZ,Blaker JJ and Boccaccini AR: Biodegradable and bioactive porous polymer/inorganic composite scaffolds for bone tissue engineering. Biomaterials 27: 3413-3431, 2006.

15. Choi D and Kumta PN: Mechano-chemical synthesis and characterization of nanostructured $\beta$-TCP powder. Materials Science and Engineering: C 27: 377-381, 2007.

16. Griffin M, Iqbal S and Bayat A: Exploring the application of mesenchymal stem cells in bone repair and regeneration. J Bone Joint Surg Br 93: 427-434, 2011.

17. Cao $\mathrm{H}$ and Kuboyama N: A biodegradable porous composite scaffold of PGA/beta-TCP for bone tissue engineering. Bone 46: 386-395, 2010.

18. Guasti L, Prasongchean W, Kleftouris G, Mukherjee S, Thrasher AJ, Bulstrode NW and Ferretti P: High plasticity of pediatric adipose tissue-derived stem cells: Too much for selective skeletogenic differentiation? Stem Cells Transl Med 1: 384-395, 2012.

19. Levi B and Longaker MT: Concise review: Adipose-derived stromal cells for skeletal regenerative medicine. Stem Cells 29: 576-582, 2011.

20. Zuk PA, Zhu M, Mizuno H, Huang J, Futrell JW, Katz AJ, Benhaim P, Lorenz HP and Hedrick MH: Multilineage cells from human adipose tissue: Implications for cell-based therapies. Tissue Eng 7: 211-228, 2001.

21. Zuk PA, Zhu M, Ashjian P, De Ugarte DA, Huang JI, Mizuno H, Alfonso ZC, Fraser JK, Benhaim P and Hedrick MH: Human adipose tissue is a source of multipotent stem cells. Mol Biol Cell 13: 4279-4295, 2002.

22. Liao HT, Chen JP and Lee MY: Bone tissue engineering with adipose-derived stem cells in bioactive composites of laser-sintered porous polycaprolactone scaffolds and platelet-rich plasma. Materials 6: 4911-4929, 2013.

23. Fang X, Murakami H, Demura S, Hayashi K, Matsubara H, Kato S, Yoshioka K, Inoue K, Ota T, Shinmura K and Tsuchiya H: A novel method to apply osteogenic potential of adipose derived stem cells in orthopaedic surgery. PloS One 9: e88874, 2014.

24. Ahn HH, Kim KS, Lee JH, Lee JY, Kim BS, Lee IW, Chun HJ, Kim JH, Lee HB and Kim MS: In vivo osteogenic differentiation of human adipose-derived stem cells in an injectable in situ-forming gel scaffold. Tissue Eng Part A 15: 1821-1832, 2009.

25. Grottkau BE and Lin Y: Osteogenesis of adipose-derived stem cells. Bone Res 1: 133-145, 2013.

26. Rehman J, Traktuev D, Li J, Merfeld-Clauss S, Temm-Grove CJ, Bovenkerk JE, Pell CL, Johnstone BH, Considine RV and March KL: Secretion of angiogenic and antiapoptotic factors by human adipose stromal cells. Circulation 109: 1292-1298, 2004.

27. Liao HT and Chen CT: Osteogenic potential: Comparison between bone marrow and adipose-derived mesenchymal stem cells. World J Stem Cells 6: 288-295, 2014.

28. Nurden AT: Platelets, inflammation and tissue regeneration. Thromb Haemost 105 (Suppl 1): S13-S33, 2011.

29. Nurden AT, Nurden P, Sanchez M, Andia I and Anitua E: Platelets and wound healing. Front Biosci 13: 3532-3548, 2008.

30. Marx RE: Platelet-rich plasma: Evidence to support its use. J Oral Maxillofac Surg 62: 489-496, 2004.

31. Marx RE, Carlson ER, Eichstaedt RM, Schimmele SR, Strauss JE and Georgeff KR: Platelet-rich plasma: Growth factor enhancement for bone grafts. Oral Surg Oral Med Oral Pathol Oral Radiol Endod 85: 638-646, 1998

32. Niemeyer P, Fechner K, Milz S, Richter W, Suedkamp NP, Mehlhorn AT, Pearce S and Kasten P: Comparison of mesenchymal stem cells from bone marrow and adipose tissue for bone regeneration in a critical size defect of the sheep tibia and the influence of platelet-rich plasma. Biomaterials 31: 3572-3579, 2010.

33. Mazzocca AD, McCarthy MB, Chowaniec DM, Dugdale EM, Hansen D, Cote MP, Bradley JP, Romeo AA, Arciero RA and Beitzel K: The positive effects of different platelet-rich plasma methods on human muscle, bone and, tendon cells. Am J Sports Med 40: 1742-1749, 2012. 
34. El Backly RM, Zaky SH, Muraglia A, Tonachini L, Brun F, Canciani B, Chiapale D, Santolini F, Cancedda R and Mastrogiacomo M: A platelet-rich plasma-based membrane as a periosteal substitute with enhanced osteogenic and angiogenic properties: A new concept for bone repair. Tissue Eng Part A 19: $152-165,2013$.

35. Wang C, Zhong D, Zhou X, Yin K, Liao Q, Kong L and Liu A: Preparation of a new composite combining strengthened $\beta$-tricalcium phosphate with platelet-rich plasma as a potentia scaffold for the repair of bone defects. Exp Ther Med 8: 1081-1086, 2014.

36. Mirhadi B, Mehdikhani B and Askari N: Synthesis of nano-sized $\beta$-tricalcium phosphate via wet precipitation. Processing and Application of Ceramics 5: 193-198, 2011.

37. Monshi A, Foroughi MR and Monshi MR: Modified Scherrer equation to estimate more accurately nano-crystallite size using XRD. World J Nano Sci Eng 2: 154, 2012

38. Tran RT, Thevenot P, Zhang Y, Gyawali D, Tang L and Yang J: Scaffold sheet design strategy for soft tissue engineering. Nat Mater 3: 1375-1389, 2010.

39. American Society of the International Association for Testing and Materials (ASTM) International: ASTM Standard D695-91: Standard test method for compressive properties of rigid plastics. In: Annual Book of ASTM Standards. 8th edition. ASTM International, West Conshohocken, PA, pp204-210, 1993.

40. Jeong SM, Lee CU, Son JS, Oh JH, Fang Y and Choi BH: Simultaneous sinus lift and implantation using platelet-rich fibrin as sole grafting material. J Craniomaxillofac Surg 42: 990-994, 2014.

41. Schneider CA, Rasband WS and Eliceiri KW: NIH Image to ImageJ: 25 years of image analysis. Nat Methods 9: 671-675, 2012 .

42. Schmittgen TD and Livak KJ: Analyzing real-time PCR data by the comparative C(T) method. Nat Protoc 3: 1101-1108, 2008.

43. Frondel C: Mineralogy of the calcium phosphates in insular phosphate rock. Am Mineral 28: 215-232, 1943.

44. Yuan H, Yang Z, De Bruij JD, De Groot K and Zhang X: Material-dependent bone induction by calcium phosphate ceramics: A 2.5-year study in dog. Biomaterials 22: 2617-2623, 2001.

45. Okamoto M, Dohi Y, Ohgushi H, Shimaoka H, Ikeuchi M, Matsushima A, Yonemasu K and Hosoi H: Influence of the porosity of hydroxyapatite ceramics on in vitro and in vivo bone formation by cultured rat bone marrow stromal cells. J Mater Sci Mater Med 17: 327-336, 2006.

46. Annaz B, Hing K, Kayser M, Buckland T and Di Silvio L: Porosity variation in hydroxyapatite and osteoblast morphology: A scanning electron microscopy study. J Microsc 215: 100-110, 2004

47. Karageorgiou V and Kaplan D: Porosity of 3D biomaterial scaffolds and osteogenesis. Biomaterials 26: 5474-5491, 2005.
48. Hulbert SF, Young FA, Mathews RS, Klawitter JJ, Talbert CD and Stelling FH: Potential of ceramic materials as permanently implantable skeletal prostheses. J Biomed Mater Res 4: 433-456, 1970.

49. Yuan J, Cui L, Zhang WJ, Liu W, and Cao YL: Repair of canine mandibular bone defects with bone marrow stromal cells and porous $\beta$-tricalcium phosphate. Biomaterials 6: 1005-1013, 2007.

50. Kasemo B: Biological surface science. Surf Sci 500: 656-677, 2002

51. Tsai WB and Wang MC: Effects of an avidin-biotin binding system on chondrocyte adhesion and growth on biodegradable polymers. Macromol Biosci 5: 214-221, 2005.

52. Balcells M and Edelman ER: Effect of pre-adsorbed proteins on attachment, proliferation, and function of endothelial cells. J Cell Physiol 191: 155-161, 2002.

53. Massia SP and Hubbell JA: Human endothelial cell interactions with surface-coupled adhesion peptides on a nonadhesive glass substrate and two polymeric biomaterials. J Biomed Mater Res 25: 223-242, 1991

54. Dekker A, Poot AA, van Mourik JA, Workel MP, Beugeling T, Bantjes A, Feijen J and Van Aken WG: Improved adhesion and proliferation of human endothelial cells on polyethylene precoated with monoclonal antibodies directed against cell membrane antigens and extracellular matrix proteins. Thromb Haemost 66: 715-724, 1991

55. Sinclair J and Salem AK: Rapid localized cell trapping on biodegradable polymers using cell surface derivatization and microfluidic networking. Biomaterials 27: 2090-2094, 2006.

56. Bhat V, Truskey G and Reichert WM: Using avidin-mediated binding to enhance initial endothelial cell attachment and spreading. J Biomed Mater Res 40: 57-65, 1998.

57. Poeschl PW, Ziya-Ghazvini F, Schicho K, Buchta C, Moser D, Seemann R, Ewers R and Schopper C: Application of platelet-rich plasma for enhanced bone regeneration in grafted sinus. J Oral Maxillofac Surg 70: 657-664, 2012.

58. Albanese A, Licata ME, Polizzi B and Campisi G: Platelet-rich plasma (PRP) in dental and oral surgery: From the wound healing to bone regeneration. Immun Ageing 10: 23, 2013.

59. Khairy N, Shendy E, Askar N and El-Rouby DH: Effect of platelet rich plasma on bone regeneration in maxillary sinus augmentation (randomized clinical trial). Int J Oral Maxillofac Surg 42: 249-255, 2013.

60. Mifune Y, Matsumoto T, Takayama K, Ota S, Li H, Meszaros LB, Usas A, Nagamune K, Gharaibeh B, Fu FH and Huard J: The effect of platelet-rich plasma on the regenerative therapy of muscle derived stem cells for articular cartilage repair. Osteoarthritis Cartilage 21: 175-185, 2013.

61. Sun Y, Feng Y, Zhang CQ, Chen SB and Cheng XG: The regenerative effect of platelet-rich plasma on healing in large osteochondral defects. Int Orthop 34: 589-597, 2010.

62. Intini G: The use of platelet-rich plasma in bone reconstruction therapy. Biomaterials 30: 4956-4966, 2009. 